\title{
Using flower strips to promote green lacewings to control cabbage insect pests
}

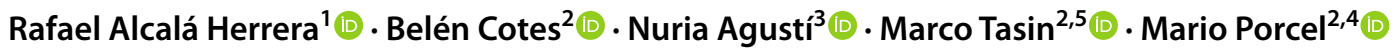

Received: 15 March 2021 / Revised: 3 August 2021 / Accepted: 4 August 2021 / Published online: 23 August 2021

(c) The Author(s) 2021

\begin{abstract}
Habitat management improves biological control by increasing the abundance and fitness of natural enemies through the provision of floral resources along field edges or between crops. Among the natural enemies reliant on flower resources, green lacewings often stand out due to their abundance, predation capacity and polyphagy. We evaluated the impact of tailored flower strips on the enhancement of natural enemies, especially green lacewings, in three organic cabbage (Brassica oleracea) farms in Southern Sweden. Insects were sampled from the flower strips, and cabbage pests and predators were visually recorded in the crop. In a laboratory assay, the pollen feeding preferences of Chrysoperla carnea (Stephens, 1836) were evaluated in a dual-choice test. The pollen consumed by the Chrysopidae was extracted from laboratory and field specimens, then quantified and identified. Flower strips were found to attract predators and parasitoids, whose abundance increased as flowers bloomed. Cabbage plants next to the flower strips showed lower pest infestation as compared to cabbage plant control, although no significant differences were observed in the number of predators. Chrysopidae used flower strips as feeding, reproduction and shelter sites and mainly consumed pollen from Phacelia tanacetifolia Benth. Under laboratory conditions, C. carnea showed a preference for P. tanacetifolia and Coriandrum sativum L. pollen over Borago officinalis L. and Fagopyrum esculentum Moench. We show that tailored flower strips could be an efficient tool for enhancing beneficial arthropods and should be considered in integrated pest management for cabbage crops.
\end{abstract}

Keywords Ecological infrastructure $\cdot$ Conservation biological control $\cdot$ Pollen $\cdot$ Chrysoperla carnea $\cdot$ Predators $\cdot$ Parasitoids

\section{Key messages}

Communicated by Antonio Biondi .

Rafael Alcalá Herrera

rafa.alcala@eez.csic.es

1 Plant Protection Group, Department of Environmental Protection, Estación Experimental del Zaidín (EEZ), Spanish National Research Council (CSIC), Granada, Spain

2 Integrated Plant Protection Unit, Department of Plant Protection Biology, Swedish University of Agricultural Sciences, Alnarp, Sweden

3 IRTA, Ctra. Cabrils Km 2, 08348 Cabrils (Barcelona), Spain

4 Corporación Colombiana de Investigación Agropecuaria (AGROSAVIA), C. I. La Libertad, Vía Puerto López km 17, Meta, Colombia

5 Department of Chemical Sciences, University of Padua, Via Marzolo 1, 35121 Padova, Italy
- Flower strips attract predators and parasitoids.

- Cabbage plants next to flower strips showed lower pest infestation levels.

- Chrysoperla carnea sensu Henry, Chrysoperla lucasina and Chrysopa commata were found in the tailored flower strips in Southern Sweden.

- Field collected Chrysopidae mainly consumed pollen from the flower strips introduced.

- Chrysopidae show a preference for feeding on Phacelia tanacetifolia and Coriandrum sativum pollen grains. 


\section{Introduction}

Increasing agricultural intensification has had a negative impact on the wider environment, which has led to landscape simplification, agrochemical spillover in soil and water, as well as an increasing loss of biodiversity (Conway 2000; Tilman et al. 2002). Farmers have been experiencing major losses of essential ecosystem services, such as pollination, water and fertility regeneration, nutrient recycling and biological pest control (Steffen et al. 2015). A shift towards a more ecosystem-based approach to agriculture has been proposed (Tittonell 2014). This approach includes habitat management in order to restore functional agrobiodiversity in the agricultural landscape. This involves the introduction of non-crop vegetation with the aim of providing beneficial arthropods with shelter, overwintering sites, alternative prey and food resources (Landis et al. 2000; Gurr et al. 2017). Over the last decades, the use of flower strips in cultivated fields in order to enhance plant diversity has attracted growing interest from researchers, farmers and practitioners (Haaland and Gyllin 2011; Penvern et al. 2019; Aparicio et al. 2021). Annual and perennial flower strips have been shown to increase beneficial arthropod diversity and biological pest control (Fiedler et al. 2008; Tschumi et al. 2016; Cahenzli et al. 2019; Albrecht et al. 2020). However, as several factors may influence the success of this strategy, system-specific evaluations need to be carried out prior to implementation (Tscharntke et al. 2016). Parameters such as time of flowering, synchronization with natural enemies and pest occurrence, nectar and pollen production and competition with the main crop for resources should be carefully investigated before this strategy is implemented. Furthermore, flower strips should not attract or host arthropods potentially harmful to the main crop or favour intraguild predation among beneficial arthropods (Tscharntke et al. 2016).

Brassica, an important arable crop in Europe, is attacked by a wide range of herbivores, including insects, nematodes, slugs and birds (Alford et al. 2003). Insects are regarded as the main source of yield losses in Swedish vegetable production, for example, the flies Delia radicum (L.) and Delia floralis (Fallen) are important pests in cabbage and cauliflower (Nilsson et al. 2016). The most economically important Brassica vegetables in Sweden are cauliflower (421 ha; 7359 ton), white cabbage (338 ha; 16362 ton) and broccoli (335 ha; 2941 ton) (SCB 2018). Several key Brassica insect pests such as Plutella xylostella $\mathrm{L}$., Pieris rapae L. and D. radicum cause substantial economic damage to Brassica crops in Sweden, although in the southern and central part of the country, other insect pests (Pieris brassicae L., Pieris napi L., Mamestra brassicae L., Autographa gamma L., Lacanobia oleracea L.,
Agrotis spp. or Evergestis forficalis L.) are frequently responsible for minor damages (Andersson et al. 2013). Furthermore, key Brassica insect pests, such as Psylliodes chrysocephala (L.), Ceutorhynchus obstrictus (Marsham) and Meligethes aeneus (Fabricius), have developed resistance to certain widely used pesticides, thus making their control increasingly difficult (Heimbach and Müller 2013). One alternative to the use of pesticides is to create a more favourable environment for locally occurring natural enemies that have the potential to control key pests (Balmer et al. 2014; Nilsson et al. 2016). For instance, Fagopyrum esculentum Moench sown as a single species or flower mixture along cabbage borders was found to improve natural lepidopteran pest control, with higher parasitism rates observed on $P$. xylostella and P. rapae, as well as increased predation on M. brassicae. However, these positive effects were not consistent throughout the studies reported (Lee and Heimpel 2005; Pfiffner et al. 2009; Winkler et al. 2009).

Green lacewings, mainly at the larval stage, prey on softbodied insects such as aphids, thrips, mites, moths and lepidopteran eggs (Principi and Canard 1984). In this context, cabbage pests such as $P$. brassicae, $P$. xylostella, $M$. brassicae and B. brassicae have been reported as green lacewings preys (Klingen et al. 1996; Reddy et al. 2004; Huang and Enkegaard 2010; Ahmad-Ur-Rahman et al. 2016). Conversely, most adults show palyno-glycophagous behaviour, with a diet based on pollen, nectar and honeydew (Stelzl 1991, 1992; Canard 2001; Villenave et al. 2006; Villa et al. 2017). Furthermore, green lacewings are one of the most studied groups of natural enemies given their important role in crop protection, as well as their presence in field crops (Villenave et al. 2005; Pappas et al. 2011). The Chrysoperla carnea-group, which includes some of the most abundant green lacewing species in agroecosystems, is comprised of at least 21 sibling species which are extremely similar in morphology (Price et al. 2015). Three or four species of the Chrysoperla carnea-group may even coexist on a single tree (Henry et al. 2013; Alcalá Herrera et al. 2019a). Studies of green lacewings rarely provide a breakdown of the Chrysoperla carnea-group into their species assemblages (e.g. Bertrand et al. 2019; Villa et al. 2019), which would give us an essential insight into the ecological differences between the different species. Chrysoperla carnea species are opportunistic feeders which are attracted to large patches of flowering plants $\left(>20 \mathrm{~m}^{2}\right.$ ) (Villenave et al. 2006; Alcalá Herrera et al. 2020).

While Villenave et al. (2006) have suggested that bordering vegetation constitutes a reservoir habitat and resting place for most Chrysopidae, mixed results have been found about the effect of cover crops and on increased lacewing activity during the cropping season (Smith et al. 1996; Bone et al. 2009). Conversely, other studies have observed that 
flowering plants in apple, citrus and olive orchards, as well as sown flower strips adjacent to cotton and cabbage crops, increased lacewing populations and recruitment into crop fields (Fye and Carranza 1972; Burleigh et al. 1973; Ridgway and Murphy 1984; Wyss 1995; Silva et al. 2010; Porcel et al. 2017). The following factors need to be taken into account when managing habitats to increase and maintain naturally occurring Chrysopidae populations (Ridgway and Murphy 1984): availability and suitability of plant species containing flowers with an ultraviolet pattern, open corollas for accessible pollen, and well-exposed nectaries (Villenave et al. 2005; Nave 2016; Van Rijn and Wackers 2016; Hatt et al. 2019); the presence of preimaginal-stage eggs and larvae indicating the suitability of the habitat as a reproduction site (Bianchi et al. 2013); improved nesting sites for a better colonization and healthier predator and parasitoid movement between these habitats adjacent to crop (Nicholls et al. 2001; Wilkinson and Landis 2005); knowledge of local population dynamics of both Chrysopidae and target pest species (Ridgway and Murphy 1984; Landis et al. 2000).

Thus, the overall goal of this study was to determine whether selected flowering plant species arranged in strips can be used to attract and support predators and parasitoids, with particular emphasis on green lacewings. In addition, we estimated the suitability of flower strips to enhance biological pest control of the lepidopterans: M. brassicae, P. xylostella, P. brassicae, $P$. rapae and the aphid Brevicoryne brassicae L. by green lacewings in organic Brassica oleracea crops. We hypothesized that adult green lacewings would be attracted to and use flower resources such as pollen and nectar and use suitable oviposition sites in adjacent cabbage crops, where their larvae would prey on the most important cabbage pests. The specific objectives of this study were: (i) to evaluate the impact of flower strips on pest and predator abundances in Brassica crops, (ii) to identify the arthropod community, especially green lacewings, associated with plant species present in the flower strips, (iii) to identify and quantify the pollen consumed by green lacewing adults collected from the flower strips and (iv) to determinate their pollen feeding preferences in a laboratory assay.

\section{Material and methods}

\section{Experimental design}

The field experiment was conducted between May and September 2017. Three commercial farms were selected in the county of Scania in the south of Sweden (Figure S1), which is dominated by arable crops and meadows. The most common crops are rye, barley, oats, wheat, sugar beet, potatoes and cabbage vegetables. All three farms were organically certified under EU regulations by KRAV Sweden. Each farm had an area planted with cabbage (B. oleracea), with three to seven varieties per farm (Table S1). In each farm, standardized $1.80 \mathrm{~m}$ wide and between 20 to $180 \mathrm{~m}$ long (farm 1: $180 \mathrm{~m}$; farm 2: 45-60 m; and farm 3: $20 \mathrm{~m}$ ) flower strips (rows) were established between May and June 2017 (Figure 1 and $\mathrm{S} 1$ ) at a distance of 1.5 to $2 \mathrm{~m}$ from the crop. The number of rows varied between two and five (Figure 1 and $\mathrm{S} 1)$. Distances between rows ranged from 3 to $9 \mathrm{~m}$, according to the grower planting diagram (Figure 1 and S1).

In the three farms, the cabbage plants were sown in two treatments: (i) adjacent to flower strips (flower strip blocks)

\section{Farm 1}

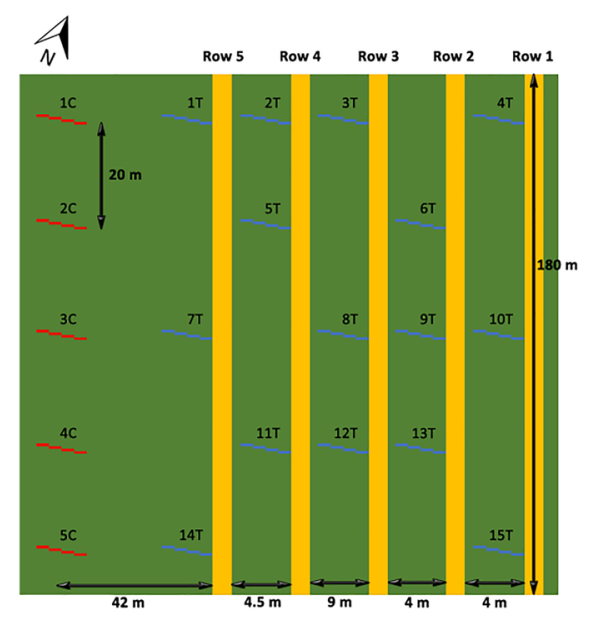

Farm 2

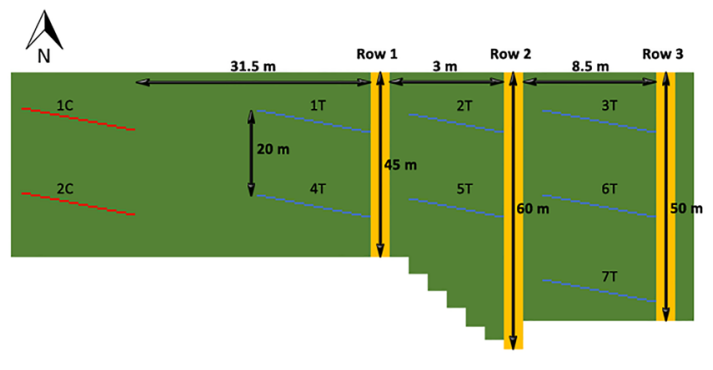

Flower strips

Cabbage crops

- Control blocks

- Flower strip blocks
Farm 3

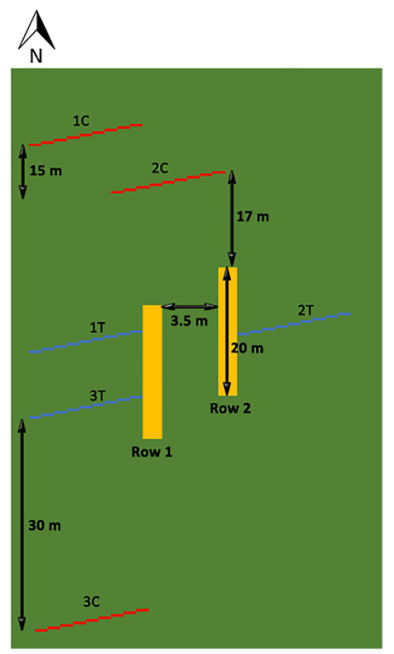

Fig. 1 Experimental design in each farm. 1C-5C are the control blocks, and 1T-15T are the flower strip blocks. The location of each farm in Scania, plant species distribution within the flower strips and seed rate per plant species are given in Figure S1 
and (ii) with no adjacent flower strips (control blocks) (Figure 1 and S1). A diagonal line of eighteen cabbage plants, randomly selected and marked the first time, was regarded as a block. The number of blocks per farm depended on the cabbage crop surface available by the grower and to maximize differences between treatments. In farm 1, there were 20 blocks ( 5 control blocks and 15 flower strip blocks), 9 blocks in farm 2 ( 2 control blocks and 7 flower strip blocks) and 6 blocks in farm 3 (3 control blocks and 3 flower strip blocks) (Figure 1 and S1). Blocks were sampled repeatedly on six to eight occasions in each farm at least once a week from June to September. The minimum distance between blocks and treatments was five and $25 \mathrm{~m}$, respectively. The minimum distance between control blocks and rows was 17 $\mathrm{m}$ (Figure 1 and $\mathrm{S} 1$ ).

The flower strips were comprised of six different plant species: Borago officinalis L., Coriandrum sativum L., F. esculentum, Foeniculum vulgare Mill., Helianthus annuus L. and Phacelia tanacetifolia Benth. (Figure S1). These species were chosen on the basis of the following two criteria: (i) floral resources had demonstrated positive effects on the survival, reproduction, development and population dynamics of lacewings (Villenave et al. 2005, 2006; Robinson et al. 2008; Van Rijn 2012; Gonzalez et al. 2016; Tschumi et al. 2016; Villa et al. 2016) and (ii) the locally adapted ecotype plant species are present throughout Sweden and around the world.

The seeds of the plant species produced under organic conditions were supplied by a company specializing in locally adapted ecotypes (Lindbloms Frö, Sweden). Plants were sown using a hand seeder in single species rows (Figure S1). Each flower strip was established coinciding with the planting schedules of the adjacent cabbage row. The presence of other flowering species in the crops was scarce, and weeds in flower strips were manually managed. Flower strips were irrigated at the same time as the cabbage crops. No pesticide treatments, mowing or fertilization was conducted in the flower strips.

Flower bloom was estimated as the percentage of open flowers (scale 0-100\%) for each plant species in each row and farm at least once a week from June to September, with a total of between six and nine times per farm. In general, the flower bloom was $27.72 \pm 3.99 \%($ mean $\pm \mathrm{SE})$.

\section{Pest and predator presence in cabbage crops}

All leaves and the stem of the cabbage plants in flower strip and control blocks were closely inspected to count and record the presence and abundance of the lepidopterans $M$. brassicae, $P$. xylostella, $P$. brassicae, $P$. rapae and the aphid species B. brassicae L., as well as the predators Chrysopidae, Coccinellidae and Syrphidae.

\section{Arthropod collection in flower strips}

Arthropod collection began on the 15th of July, approximately seven weeks after sowing the flower strips, once the flowers started to bloom, and came to an end on the 1st of September. Suction samples were taken from the flower strips on a weekly basis using a Stihl® SH 85C aspirator (Stihl AG \& Co, Waiblingen, Germany). For each sample, the aspirator was moved across the flower strip for $40 \mathrm{sec}-$ onds covering all plant species. The sampling points within the flower strip were selected randomly, with a minimum distance of four metres between samples. The number of samples per farm ranged from eight to 30 on each sampling occasion. Suction samples were transported under cold conditions and stored in a freezer at $-20{ }^{\circ} \mathrm{C}$ until identification.

The arthropods collected were counted and identified to family and genus level where possible using standard taxonomic keys (Goulet et al. 1993; Barrientos 2004). We pooled the individuals collected into two groups: predators (Chrysopidae, Coccinellidae, Cantharidae, Anthocoridae, Deraeocoris sp. and Nabidae) and parasitoids (Ceraphronidae, Megaspilidae, Aphelinidae, Encyrtidae, Eulophidae, Mymaridae, Pteromalidae, Torymidae, Cynipidae, Figitidae, Braconidae, Ichneumonidae, Platygastridae, Diapriidae and Proctutropidae).

The Chrysopidae larvae were determined under a stereomicroscope to genus level based on larval cephalic chaetotaxy (Monserrat 2016). Chrysopidae adults were sexed and identified to species level as described by Plant (2013) and Aspöck et al. (1980). Apart from Chrysoperla lucasina (Lacroix, 1912), cryptic species of the Chrysoperla carnea-group were identified to species level, according to the method described by Henry et al. (2002) and Chapman et al. (2006), by measuring the basal dilation of the metatarsal claw and the genital lip and chin of the male abdomen, and the values were compared to those reported by Henry et al. (2002).

\section{Pollen-foraging preference assay}

A laboratory assay was performed in August 2017 to assess the pollen-foraging preferences of the common green lacewing, Chrysoperla carnea (Stephens, 1836), for the different plant species used in the field experiment. A colony was established for the trial, with lacewing individuals provided by Sautter \& Stepper GmbH (Ammerbuch-Altingen, Germany). Chrysoperla carnea adults were fed with a mix of organic multi-flower honey (Ekologisk honung, COOP, Sweden) and pollen (Bipollen, Life, Sweden) $(1: 1 \mathrm{v} / \mathrm{v})$ and kept in a plastic cage $(31 \times 21 \times 12 \mathrm{~cm})$ which was placed in a climatic chamber under controlled conditions at $25 \pm 2{ }^{\circ} \mathrm{C}$, 50-60\% humidity and 16:8 hours L:D photoperiod. Larvae were fed ad libitum with Ephestia kuehniella Zeller eggs (Biotop, Livron-sur-Drôme, France) until pupation. Newly 
emerged adults were sexed and starved for $24 \mathrm{~h}$. A female and a male $C$. carnea were placed inside a plastic cage (18 $\times 18 \times 10 \mathrm{~cm}$ ) with a couple of fresh well-developed flowers with the stems in a $25 \mathrm{ml}$ water cup with all possible plant species pairs combinations. Flowers were obtained from fresh plant material collected daily from the flower strips and kept in water. Adults were allowed to feed on the flowers for $24 \mathrm{~h}$. They were then immediately frozen at $-20{ }^{\circ} \mathrm{C}$ for gut content analysis. Six replicates of all pairs combinations were run, with a total of 72 C. carnea adults assayed (36 females and 36 males).

To analyse pollen consumption, the acetolysis technique was used for protein, lipid and insect tissue digestion, which facilitated accurate pollen identification (Jones 2014). This methodology has been previously used to study gut content in Chrysopidae adults (Medeiros et al. 2010; Andrade et al. 2017; Resende et al. 2017; Villa et al. 2019). Prior to acetolysis, wings, legs and antennae were removed from defrosted adults at room temperature to reduce residues following acetolysis. Each specimen was placed in a $2 \mathrm{ml}$ microcentrifuge tube filled with $96 \%$ ethanol, where it was vortex-washed three times to remove external pollen on the cuticle. It was subsequently transferred to another microcentrifuge tube with $0.5 \mathrm{ml}$ of glacial acetic acid to eliminate any residual water from the sample and was then crushed with a micropestle. Then, $0.5 \mathrm{ml}$ of an acetolysis mixture of glacial acetic acid and sulphuric acid (9:1) was added and heated at $100{ }^{\circ} \mathrm{C}$ in a dry heater for $8 \mathrm{~min}$. Afterwards, $0.5 \mathrm{ml}$ of glacial acetic acid was added to stop the acetolysis process and centrifuged for $10 \mathrm{~min}$ at $10000 \mathrm{rpm}$, and the supernatant was discarded. The remaining reagents were removed by washing each sample three times with $1 \mathrm{ml}$ of distilled water and then centrifuged for $3 \mathrm{~min}$ at $10000 \mathrm{rpm}$. The supernatant was discarded and the sample was placed in a fume hood at $70{ }^{\circ} \mathrm{C}$ for $12 \mathrm{~h}$ to evaporate the remaining distilled water.

For microscope slide preparation, $10 \mu \mathrm{l}$ of $99 \%$ glycerine:distilled water (1:1) were added to the microcentrifuge tube, mixed with the sample, placed on the slides and protected by a glass coverslip sealed with nail varnish.

For pollen examination, three traverses were carried out across the coverslip at the centre of each slide under a microscope at 400X for pollen grain counting and 1000X for identification. Pollen grains were identified based on their morphological polar and equatorial axes, shape, aperture and exine ornamentation traits (Punt and Clarke 1980; Valdés et al. 1987; Faegri and Iversen 1989). The results obtained were compared with the surrounding vegetation present in the farm, the reference pollen collection from fresh flowers obtained from the flower strips and slides of Chrysopidae adults feeding on a single plant species. As pollen grain size varies enormously between plant species (Punt and Clarke 1980), we measured pollen consumption in two different ways: as the number of pollen grains and as the volume of these pollen grains, as described by Buchmann and O'Rourke (1991).

Once the Chrysopidae adults collected in the field were identified to species level, their gut contents were examined following the methodology described above.

\section{Statistical analysis}

We analysed the data using R version 3.6.3 (R Development Core Team 2017) and R Studio version 1.1.456 (RStudio Team 2016), with packages glmmTMB, (Brooks et al. 2017), Matrix (Bates and Maechler 2019), Ime4 (Bates et al. 2014) and vegan (Oksanen et al. 2018). For each model, residuals were examined for model validation using package DHARMa (Hartig 2018). We checked fixed factors for significance using Wald test from the car package (Fox and Weisberg 2019) and multiple comparisons between levels of the fixed factor were tested using Tukey's test with the packages lsmeans and emmeans (Lenth 2016, 2020).

To investigate the effect of farm and flower bloom on the number of predators and parasitoids collected in flower strips, suction sampling data were analysed using generalized linear mixed models (GLMMs). In each model, flower strips (row number) and sampling date were established as random effects to account for repeated measures on the same row at different times and population dynamics variation, respectively. Models were corrected for overdispersion by using a negative binomial (NB) distribution or by adding a quasi-Poisson structure (Table S3). We used non-metric multidimensional scaling (NMDS) based on the Bray-Curtis distance to graphically represent the level of association between the different predator and parasitoid groups and the farm and flower bloom for each plant species. For each NMDS, stress was checked using the goodness plot and the Shepard stress test. A permutational multivariate analysis of variance (PERMANOVA) using Bray-Curtis distance and 999 permutations was performed to test whether predator and parasitoid communities differed between farms and were affected by flower bloom of the different plant species.

The visual sampling data revealed a low number of pests and predators in cabbage plants. Thus, and to account for zero inflation, we used hurdle generalized linear mixed models (hurdle GLMMs) with a negative binomial (NB) error distribution for parasitoids and Poisson for predators, to investigate the effect of floral attractiveness, farm and treatment (control blocks and flower strip blocks) on the number of pests and predators. In each model, block number was set as random effect to correct for repeated measures over time.

To analyse pollen-foraging preferences, the number and volume of pollen grains from the dual-choice assay were analysed using GLMMs with a NB distribution and linear 
mixed effect models (LMMs), respectively. A GLMM and a LMM were run for each pair of plants. Models included plant species and lacewing gender as fixed factors and specimen as random effect due to the paired data recorded on the same combination of plant species. Furthermore, separate NB GLMM and LMM were used for the whole dataset to establish the differences between genders in number and volume of pollen grains consumed. In each of these models, gender was included as fixed factor and specimen and plant species were set as random effects.

To analyse the pollen identified in the gut of the Chrysopidae collected by suction sampling from the field experiment, we used a GLMM with a NB distribution for number of pollen grains and a LMM for the volume of pollen grains. The models included gender, plant species (B. officinalis, $C$. sativum, F. esculentum and/or P. tanacetifolia), Chrysopidae species (Chrysopa commata data were excluded due to the low number of adults collected) and flower bloom of each plant species in the specific row where the Chrysopidae adults were collected as fixed effects. The interaction term between plant species and flower bloom was included to explore the effect of bloom at different times on pollen utilization by lacewings. Both models included farm as random effect.

\section{Results}

\section{Impact of flower strips on pests and predators in cabbage crops}

The number of pests and predators recorded by visual inspection in cabbage plants throughout the season was, respectively, $5.68 \pm 1.15$ (mean $\pm \mathrm{SE}$ ) and $0.23 \pm 0.04$ individuals per block (Fig. 2 and Table S2). The abundance of cabbage pests remained low during almost the whole sampling period, with a sharp increase observed at the end of August (Fig. 2b). Of the five pest species found in this study, $P$. brassicae and P. rapae were the most abundant (Fig. 2b and Table S2). We observed a drastic reduction in pest abundance in flower strip blocks $(4.06 \pm 0.89)$ compared with control blocks $(9.32 \pm 3.11)$ (Hurdle model, $\chi^{2}=9.6$, d.f. $=1, P<0.01$ ) (Fig 3 and Table S3), farm (Hurdle model, $\chi^{2}=15.1$, d.f. $\left.=2, P<0.001\right)$ and flower bloom variables (Hurdle model, $\chi^{2}=6.4$, d.f. $=1, P=0.012$ ) (Table S3).
Fig. 2 Number of a predators and $\mathbf{b}$ pests (mean $\pm \mathrm{SE}$ ) recorded on each sampling date by visual inspection of the cabbage plant blocks. The heatmap shows the bloom percentage for each plant species in the flower strips

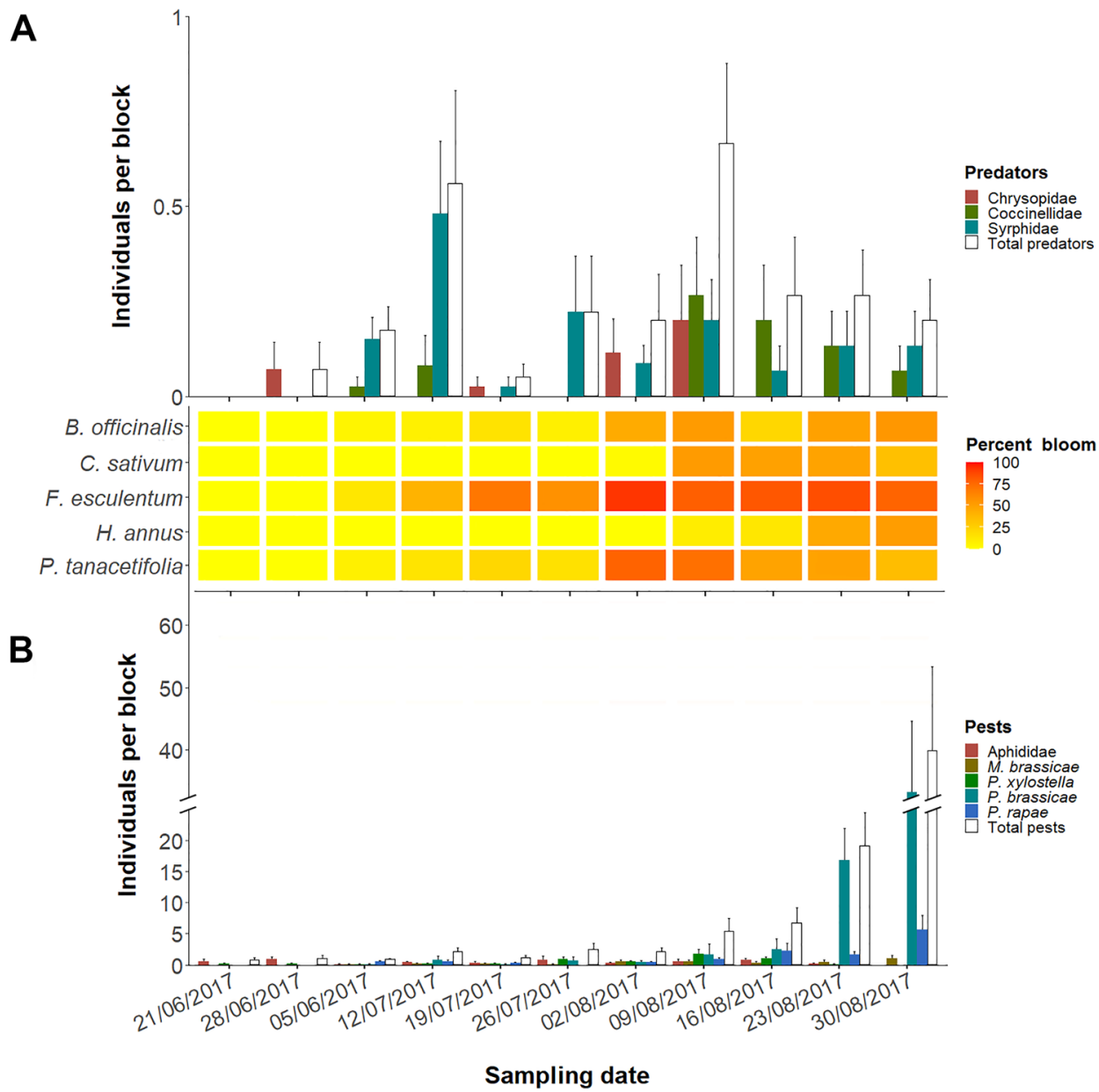




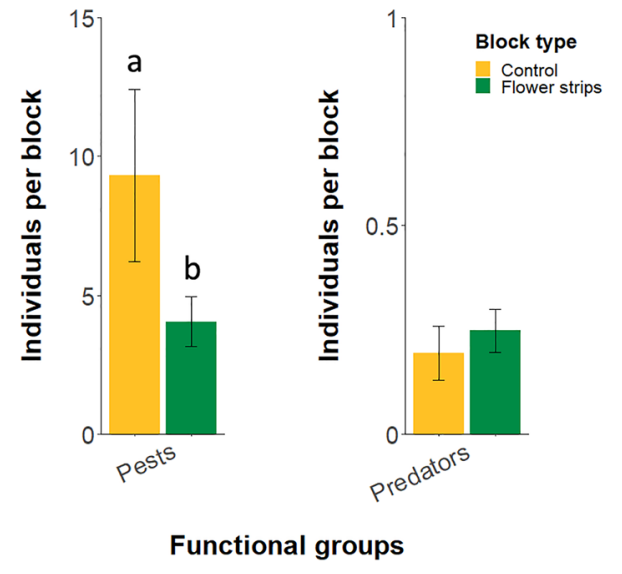

Fig. 3 Number of predators and pests (mean \pm SE) recorded in blocks situated in the vicinity of flower strips and in the control blocks through visual inspection of cabbage plants. Different letters indicate statistically significant differences between treatments (Wald test, $P<0.05)$

Predators showed two peaks of abundance in the middle of July and at the beginning of August (Fig. 2a). The most common predatory taxa found were Coccinellidae, Syrphidae and Chrysopidae (Table S2). The abundance of predators in the crop was not influenced by any of the three variables tested (Hurdle model, $P>0.050$; Table S3 and Fig. 3).

\section{Arthropod collection in flower strips}

A total of 38,081 arthropods were collected from the flower strips. Diptera were the most abundant, accounting for $50.2 \%$ of the total, followed by Thysanoptera $(13.81 \%)$ and Coleoptera (5.42\%) (Table S4).

In terms of functional groups, parasitoids represented $17 \%$ of the total arthropods collected, with 6,349 individuals, with the families Pteromalidae $(4.8 \%)$, Braconidae (3.61\%) and Eulophidae $(3.51 \%)$ being the most abundant. Predators, accounting for $2.59 \%$ of the total, belonged to the groups Orius sp. (0.95\%), Syrphidae (0.64\%), Anthocoris sp. $(0.46 \%)$, Neuroptera $(0.33 \%)$; Coccinellidae $(0.12 \%)$, Deraeocoris sp. (0.05\%), Cantharidae $(0.03 \%)$ and Nabidae $(0.01 \%)$ (Table S4). The number of predators and parasitoids gradually increased over the sampling period from the beginning of July to the highest peak of abundance at the end of August (Fig. 4a, b). The abundance of both these natural enemies also rose significantly with increasing percentages of flower bloom in the flower strips (predators GLMM, $\chi^{2}$ $=3.9$, d.f. $=1, P=0.047$; parasitoids GLMM, $\chi^{2}=14.2$,
Fig. 4 Number of a predators and $\mathbf{b}$ parasitoids (mean $\pm \mathrm{SE}$ ) on each sampling date collected by suction sampling from the flower strips. The heatmap shows the percent bloom of each plant species in the flower strips

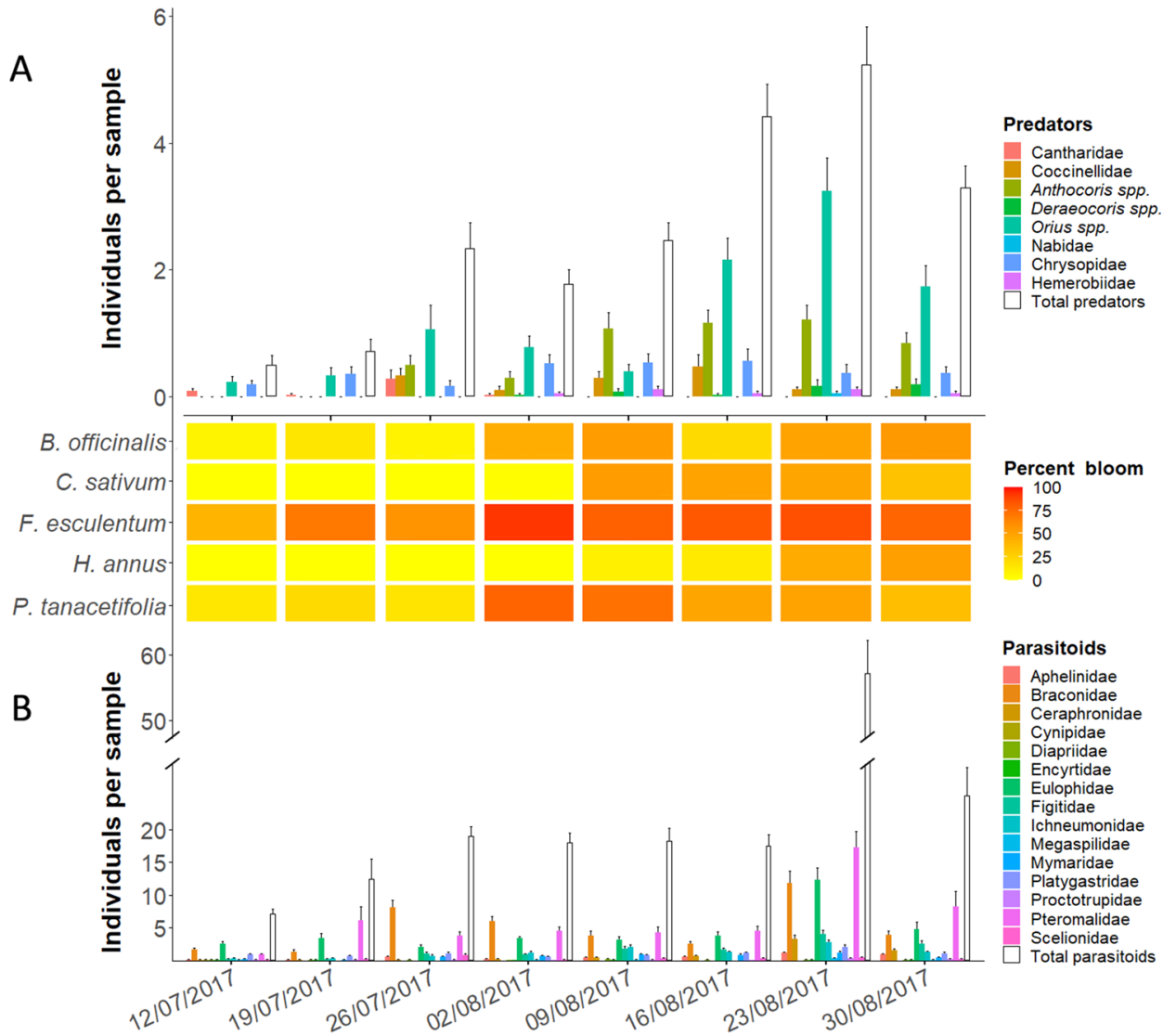

Sampling date 
d.f. $=1, P<0.001)($ Fig 5 and Table S3). Predatory insect community analysis showed significant differences between farms (PERMANOVA, $R^{2}=0.546$, Pseudo-F $=16.2$, d.f. $=$ $2, P<0.001$ ), but no flower bloom effect (PERMANOVA, $R^{2}=0.040$, Pseudo-F $=2.5$, d.f. $=2, P=0.076$ ) on community composition (Fig. 6a and Table S5). Cantharidae was associated with $P$. tanacetifolia bloom, while Coccinellidae, Orius sp., Anthocoris spp. and Deraeocoris spp. were associated with $B$. officinalis, $F$. esculentum, $C$. sativum and H. annus bloom (Fig 6a and Table S5). The parasitoid community was significantly affected by both farm (PERMANOVA, $R^{2}=0.494$, Pseudo-F $=17.1$, d.f. $=2$, $P<0.001$ ) and flower bloom (PERMANOVA, $R^{2}=0.102$, Pseudo-F $=7.1$, d.f. $=2, P<0.01)($ Fig $6 \mathrm{~b}$ and Table S5). Encyrtidae were associated with $C$. sativum and $H$. annus bloom, while Megaspillidae and Torymidae were associated with $B$. officinalis and $F$. esculentum bloom. The other parasitoid families were associated with $P$. tanacetifolia bloom (Fig 6b).

\section{Pollen consumption by Chrysopidae}

Chrysoperla carnea individuals tested in the dual-choice laboratory assay consumed significantly more pollen from the paired plant species $P$. tanacetifolia and $C$. sativum as compared to $F$. esculentum and $B$. officinalis, with no differences observed between either paired plant species (Fig. 7a and Table S3). The overall number of pollen grains
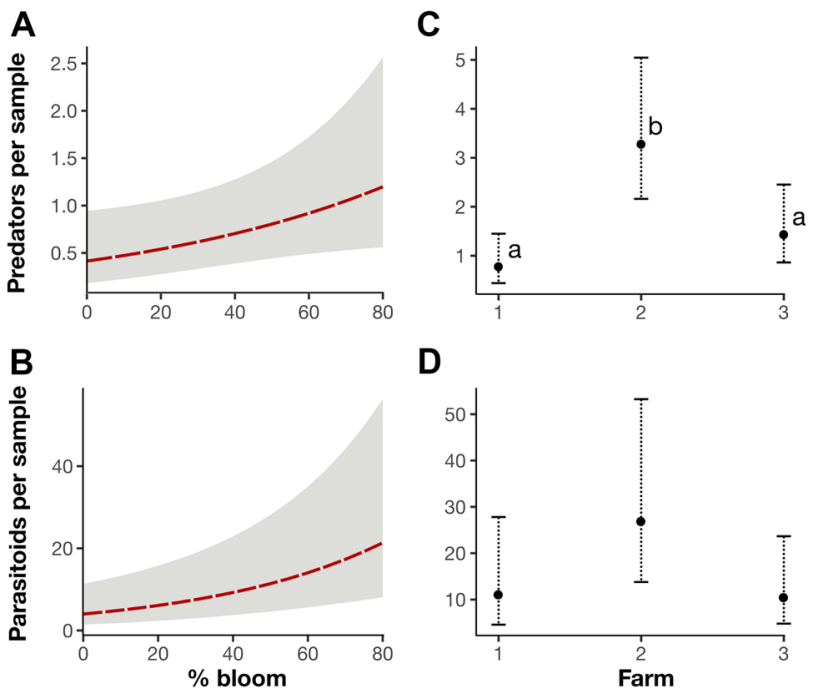

D

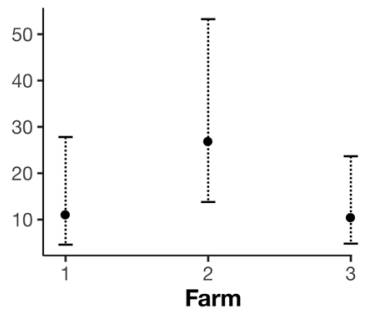

Fig. 5 Predicted GLMM values $( \pm 95 \%$ CI) for the relationship between mean percentage of flower bloom in the flower strips and a predators $\left(\chi^{2}=3.9\right.$, d.f. $\left.=1, P=0.047\right)$ and $\mathbf{b}$ parasitoids $\left(\chi^{2}=\right.$ 14.2, d.f. $=1, P<0.001)$ per suction sample, and $\mathbf{c}$ predators $\left(\chi^{2}\right.$ $=17.9$, d.f. $=2, P<0.001)$ and $\mathbf{d}$ parasitoids $\left(\chi^{2}=4.8\right.$, d.f. $=2, P$ $=0.092)$ per sample in the different farms. Different letters indicate statistically significant differences between farms (Tukey's test, $P<$ $0.05)$ consumed was significantly higher for females as compared to male specimens (Fig. 7c and Table S3). The volume of pollen consumed by lacewings yielded the same results for plant species and gender as for the number of pollen grains (Fig $7 \mathrm{~b}$ and $\mathrm{d}$ and Table S3).

A total of 54 adults (35 females and 19 males) and 59 larvae from the Chrysopidae family were captured in the flower strips. 48.2\% (19 females and 7 males) were identified as Chrysoperla carnea (Stephens, 1836) sensu Henry, 42.6\% (14 females and 9 males) as C. lucasina and 9.3\% (2 females and 3 males) as Chrysopa commata Kis \& Újhelyi, 1965. 71.2\% (42 individuals) of the 59 larvae collected were identified at genus level as Chrysoperla $s p$. Steinmann, 1964 and 28.8\% (17 individuals) as Chrysopa sp. Leach 1815.

We counted a total of 112,319 pollen grains from the 54 Chrysopidae adult guts, six of which contained no pollen. Despite feeding on all plant species present in the flower strips, the most consumed pollen was $P$. tanacetifolia in terms of quantity and total volume, as well as in the sampling period (Fig. 8a, Fig. 9 and Table S3). A small percentage $(5.61 \%)$ of the pollen consumed corresponded to other plant taxa such as the families Asteraceae (1.24\%), Brassicaceae (3.32\%), Cariophyllaceae $(0.59 \%)$, Pinaceae $(0.001 \%)$, Poaceae $(0.18 \%)$, Polygonaceae $(0.03 \%)$ and Rosaceae $(0.19 \%)$. No statistical differences were detected between Chrysopidae species (Fig 8b and Table S3). In addition, Chrysopidae females were observed to consume more pollen than males (Fig 8c and Table S3).

\section{Discussion}

The use of tailored flower strips as a conservation biological control strategy has been gaining traction in recent years, both as a research topic and in practical application terms (Gurr et al. 2017). This type of habitat manipulation strategy benefits from a cropping system-specific design and laboratory research, and requires multiple-year field testing showing pest control to achieve its full potential, to prevent failure and to improve adoption. In this study, we show that the implementation of tailored flower strips increases biodiversity and enhances natural enemy populations in cabbage crops. Through visual inspection, we demonstrated that flower strips in their vicinity have a positive impact on pest reduction in cabbage plants as compared to those in control blocks although, due to space constraints, we were forced to limit the amount of control blocks in each farm. Arguably, with a higher replication differences between treatments would have been more marked; however, we cannot discard a reduction in the pest pressure variability covered by our control plots that could have affected the results obtained. Furthermore, we cannot totally discard a certain interference of the flower strips on control blocks 
Fig. 6 Non-metric multidimensional scaling (NMDS) biplot representing the community composition of a predators (stress $=0.156$ ) and $\mathbf{b}$ parasitoids (stress $=0.143$ ) collected by suction sampling from the flower strips. Coloured dots indicate different farms, and black dots indicate the position of predator and parasitoid groups in the multivariate space. Plant species in relation to the predators and parasitoids are represented by orchidcoloured arrows. Farms differed in relation to both predator and parasitoid communities (PERMANOVA, Pseudo- $F=16.2$, $P<0.001$; Pseudo- $F=17.1$, $P<0.001$; respectively). The parasitoid community composition was affected by the bloom rate of the plant species in the flower strips (PERMANOVA, Pseudo- $F=7.1, P<0.01)$
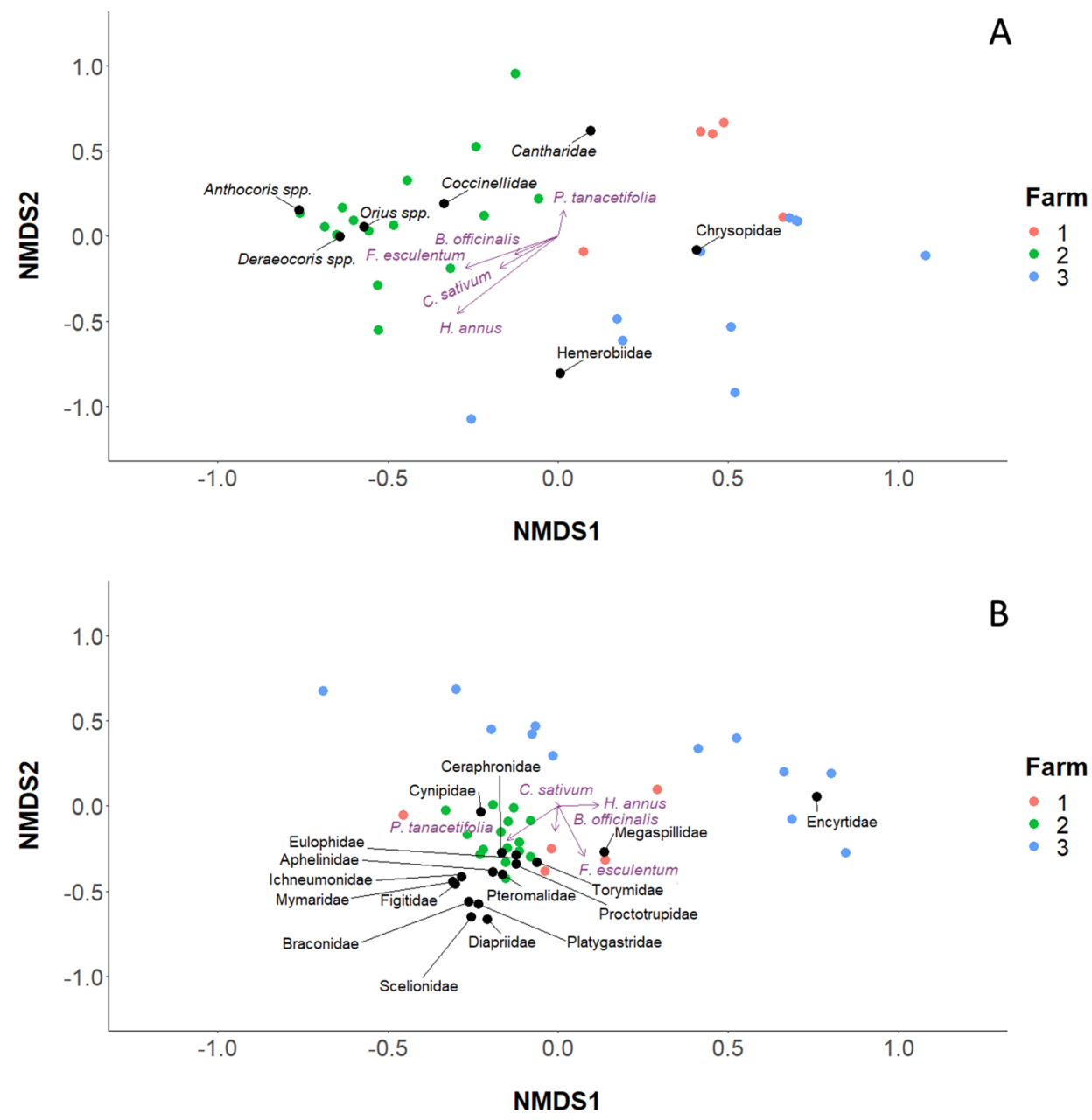

due to the high mobility of the natural enemies attracted to the flower strips, such as lacewings, and the distances established in our experimental design. Our findings are in line with other studies of biocontrol with regard to P. xylostella, $P$. rapae and $M$. brassicae in the presence of flowering plants (Zhao et al. 1992; Lee and Heimpel 2005; Pfiffner et al. 2009; Winkler et al. 2009). For instance, B. officinalis, $C$. sativum, $F$. vulgare and $P$. tanacetifolia have previously been reported to be effective attractants of natural enemies such as Coccinellidae, Syrphidae, Chrysopidae and certain parasitoids (Colley and Luna 2000; Morris and Li 2000; Verkerk 2001; Boller et al. 2004; Sievwright et al. 2006; Alcalá Herrera et al. 2019b). Surprisingly, the large presence of predators and parasitoids on the flower strips did not increase their populations on adjacent cabbage plants. Cabbage pest populations were low in the study area at the time of the study according to the growers and our own observations. This may explain why predators preferred to remain in the flower strips, where more resources were available. Furthermore, we recorded other generalist predators in the flower strips, such as Araneae, Anthocoridae, Carabidae and Dermaptera (Cahenzli et al. 2019) which may contribute to the reduction in pest populations in the vicinity of the flower strips, although these generalist predators were not recorded on the cabbage plants in our study.

It has been well established that an increase in landscape heterogeneity in terms of composition and configuration promotes natural enemies on agricultural land (Fahrig et al. 2011; Martin et al. 2019; Serée et al. 2020). We found that farm location had a major impact on predatory communities. For instance, the higher density of surrounding trees in farm 2 may have improved the abundance of predators collected compared to farms 1 and 3. Previous studies have reported that predators such as Chrysopidae, Coccinellidae and Syrphidae are attracted to flowering plants (Bertolaccini et al. 2011; Hatt et al. 2017), which is consistent with the predator community that we identified from suction samples. We show that parasitoid abundance was closely correlated with flower bloom, indicating a high attraction to plant resources in the cropping system of a large number of families within this group. This finding corroborates a simulation model developed by Bianchi and Wäckers (2008), which suggests that parasitoid aggregation in flower strips is due to feeding on floral nectar. Furthermore, Irvin et al. (2006) have shown 
A

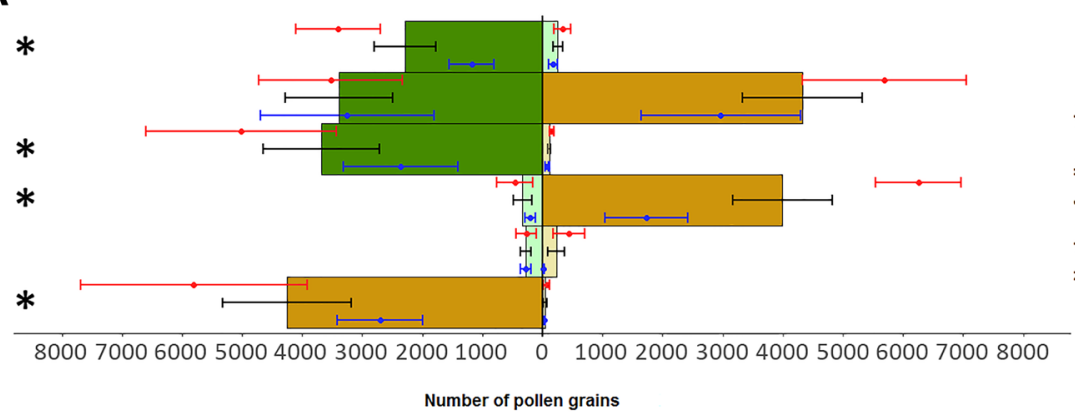

C

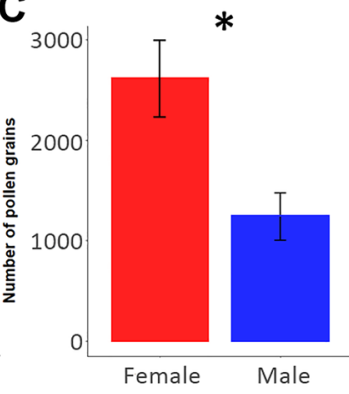

B

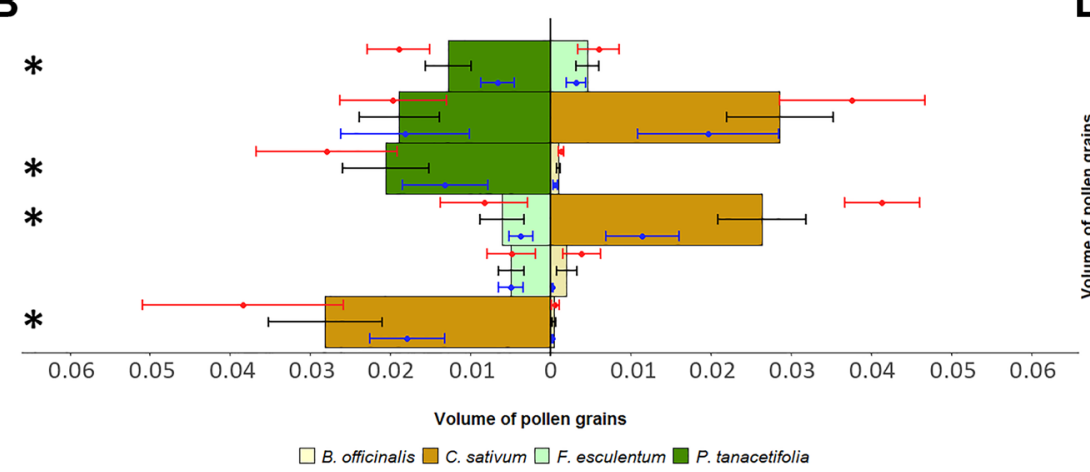

D

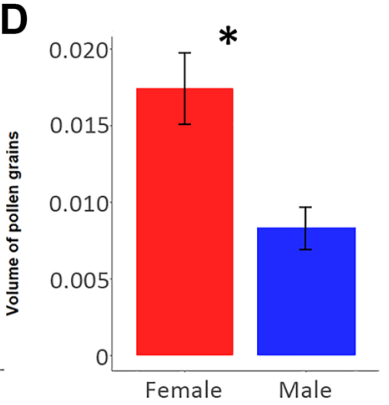

Fig. 7 a Number and $\mathbf{b}$ volume $\left(\mathrm{mm}^{3}\right)$ of pollen grains (mean \pm black $\mathrm{SE}$ ) consumed by all $C$. carnea tested in each dual-choice combination. $\mathbf{c}$ Number and $\mathbf{d}$ volume of pollen grains consumed by gender (mean \pm black SE) for the whole trial. The red dots and error bars (mean $\pm \mathrm{SE}$ ) in $\mathbf{a}$ and $\mathbf{b}$ represent pollen consumption by females and the blue dots and error bars (mean $\pm \mathrm{SE}$ ) represent pollen consumption by males for each combination. Significant differences in number and volume of pollen grains consumed between paired plants and between genders are indicated with an asterisk (GLMM, Wald test, $P$ $<0.05)$
A

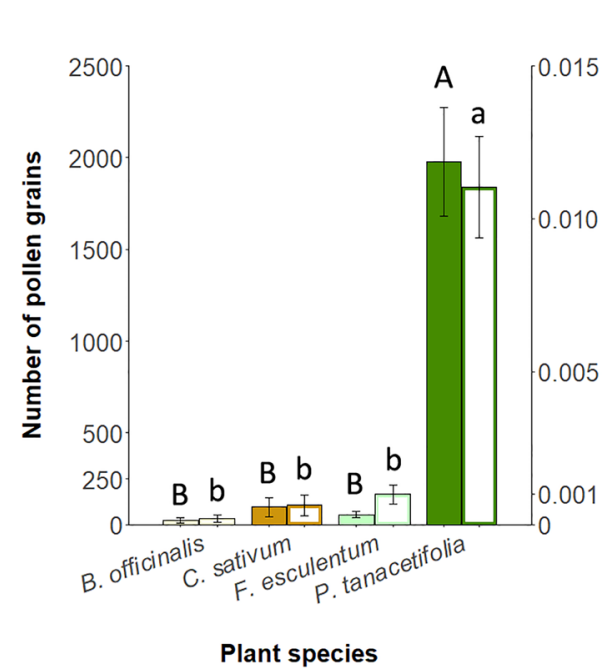

B

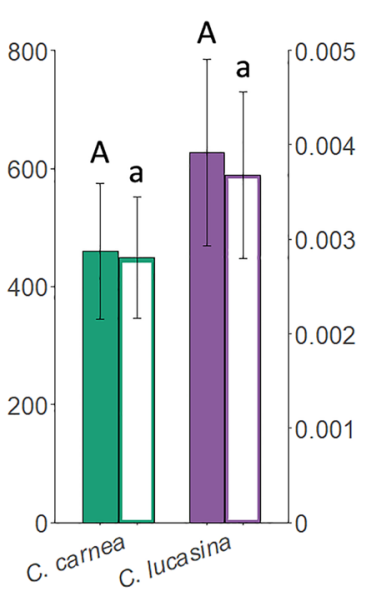

Chrysopid species
C

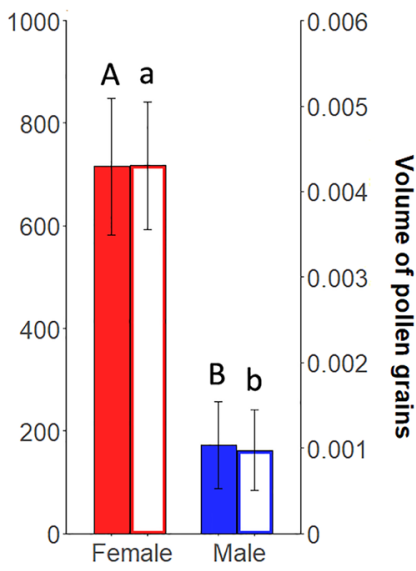

Gender
Fig. 8 Number (left axes) and volume $\left(\mathrm{mm}^{3}\right)$ (right axes) of pollen grains (mean \pm SE) consumed by the Chrysopidae collected from the flower strips by a plant species, $\mathbf{b}$ Chrysopidae species and $\mathbf{c}$ gender. Solid bars represent the number of pollen grains and hollow bars rep- resent the volume of pollen grains. Significant differences are indicated by upper-case letters for the number of pollen grains and lowercase letters for the volume of pollen grains (GLMM, Turkey's tests, $P$ $<0.05)$ 
Fig. 9 a Number and b volume of pollen grains $\left(\mathrm{mm}^{3}\right)($ mean \pm $\mathrm{SE})$ consumed by the Chrysopidae collected from the flower strips in each sampling date. The heatmap represents the bloom percentage for each plant species in the flower strips

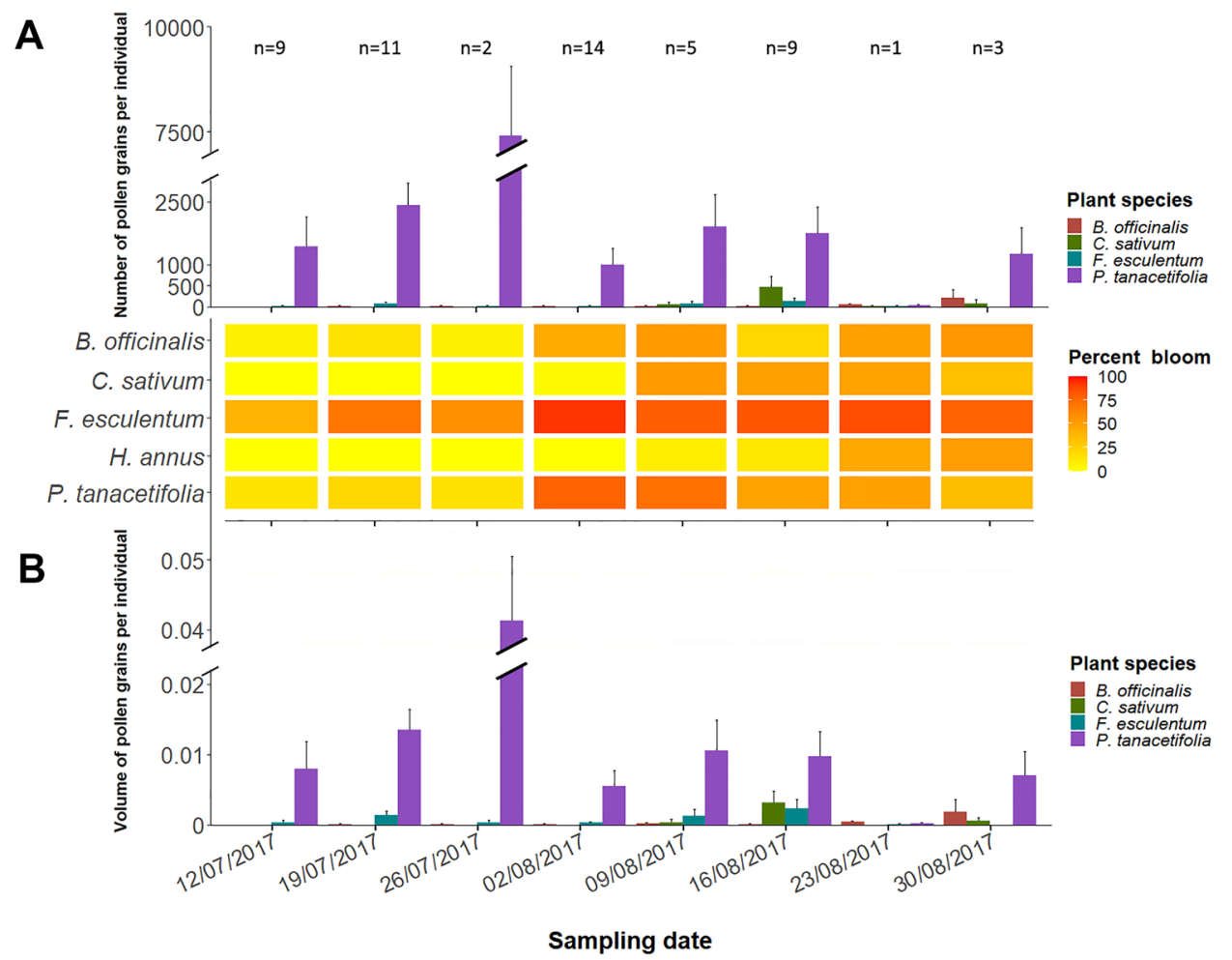

that the longevity of parasitoids fed on F. esculentum flowers was enhanced as compared to those fed on P. tanacetifolia. While predator abundance also correlated with flower bloom, predatory insect community composition was unaffected by the presence of flowers.

The Chrysopidae species assemblage in flower strips was composed of three species, $C$. carnea sensu Henry, $C$. lucasina and $C$. commata. This is the first record in Sweden of $C$. commata and $C$. lucasina to the best of our knowledge. Both Chrysoperla carnea sensu Henry and C. lucasina, which have a palyno-glycophagous diet, are frequently found in crops associated with herbaceous vegetation substrates (Canard 2001). In our study, Chrysopidae appeared to use the pollen resources provided by the flower strips, as evidenced by the ingested pollen, which belonged to the plant species sown in the flower strips. Furthermore, the number of pollen grains was correlated with the blooming period of their flowers. These results are in line with the findings of Bertrand et al. (2019), who observed that the majority of pollen consumed by $C$. carnea came from non-agricultural adjacent plants, even in crop-dominated landscapes, shifting from woody plant species in spring to herbaceous plants in the summer. In contrast, Villa et al. (2019) found an opposite trend, with $C$. carnea feeding mainly from olive pollen, rather than non-agricultural plants during the whole year. Chrysoperla carnea and C. lucasina are known to be opportunistic feeders that consume pollen according to flowering plant availability by blooming period and abundance (Villenave et al. 2006; Alcalá Herrera et al. 2020). This apparent lack of specificity in feeding habits may underlie the contrasting results obtained in gut analysis of lacewings collected from different crops and adjacent vegetation. Chrysoperla carnea sensu Henry is considered a more polyphagous feeder than C. lucasina. Chrysoperla lucasina may prefer field crops and herbaceous plants, while $C$. carnea sensu Henry feeds on pollen from trees and herbaceous plants (Villenave et al. 2005). However, we found that $C$. carnea sensu Henry and $C$. lucasina collected in the field fed mainly on $P$. tanacetifolia pollen with no differences observed between either Chrysopidae species. Furthermore, under laboratory conditions, we determined that $C$. carnea prefers to consume pollen from $P$. tanacetifolia and $C$. sativum, with no differences being observed between either plant species. The tailored flower strips also attracted C. commata, another Chrysopidae species. Despite being predators, gut content analysis of $C$. commata adults also revealed pollen consumption, which is explained by the omnivorous feeding behaviour of Chrysopa spp. (Stelzl 1991, 1992; Canard 2001). We also observed that Chrysopidae females consumed a larger number of pollen grains as compared to males. This finding, which has been reported by other authors, is explained by the additional nutrients required by females for reproduction (Villenave et al. 2005; Alcalá Herrera et al. 2020). Flower strips were also found to be used as reproduction and shelter sites by Chrysopa sp. and Chrysoperla spp., as evidenced by the larval stages 
identified from the suction samples. This is in line with previous studies which have reported preimaginal-stage larvae and/or eggs on non-agricultural grass plants and flowering plants (McEwen and Ruiz 1994; Alcalá Herrera et al. 2019b)

\section{Conclusion}

Our study shows the capacity of tailored flower strips to attract and support natural enemies, particularly green lacewings, in the cabbage agroecosystem. Chrysoperla carnea sensu Henry and C. lucasina were the most frequently collected Chrysopidae species in the flower strips. The identification of $P$. tanacetifolia, B. officinalis, F. esculentum and $C$. sativum pollen in the guts of Chrysopidae demonstrates that green lacewings feed from the plant species selected. Furthermore, our laboratory assay, which confirmed the feeding behaviour observed in the field, showed that $P$. tanacetifolia and $C$. sativum pollens were preferred by $C$. carnea sensu Henry and $C$. lucasina with no significant differences observed between either species. Finally, the presence of Chrysopidae larvae on flower strips proves that green lacewings adults use these sites for reproduction and shelter. Thus, in order to enhance conservation biological control in cabbage crops, we recommend using $P$. tanacetifolia, $C$. sativum and $F$. esculentum in flower strips to attract and support natural enemy populations, specifically those of Chrysopidae. However, further research is required to link pest reduction with natural enemy presence and explore the optimal flower strip designs in relation to crop surface. Long-term field studies are required to establish the full potential of our tailored flower strips on biological control services in cabbage and their interaction with local landscape configuration.

\section{Author contribution statement}

$\mathrm{BC}$ acquired the funding and performed in supervision. $\mathrm{BC}$ and MT administered the project. BC, NA and RAH took part in conceptualization. BC and RAH selected the methodology and carried out the investigation. MP and RAH carried out formal analysis and was involved in visualization. RAH wrote the original draft. BC, MP, MT, NA and RAH took part in writing, reviewing and editing. All the authors revised and approved the manuscript.

Supplementary Information The online version contains supplementary material available at https://doi.org/10.1007/s10340-021-01419-7.
Acknowledgments We wish to thank Elisabeth Örgen and Christina Winter (Jordbruksverket) not only for helping to make the project possible, but also for their invaluable assistance and comments, as well as Matthieu Laurent for field and laboratory assistance. We owe special thanks to the local farmers, Biskopshagens Odlingar, Mossagårdens Ekologiska Odling and Gårdsbutik, Kåsebergaodlingen Skåne, for granting us the use of their properties. We would also like to thank Oskar Hansson, Anna-Mia Björkholm (Hushållningssällskapet), Teun Dekker and Mattias Jonsson (SLU) for their advice and assistance, as well as Anne Birgitte Nielsen (Lund University) and Victor Monserrat, (Complutense University of Madrid) for resolving pollen and lacewing identification issues. Mercedes Campos and Javier Palenzuela (EEZ-CSIC) assisted with the production of pollen images and Michael O'Shea proofread the manuscript.

Funding Open Access funding provided thanks to the CRUE-CSIC agreement with Springer Nature. The study was financed by SLU Ekoforsk at the Swedish University of Agricultural Sciences (Project number 2016.4.1-742-4).

Data availability The data are available at https://digital.csic.es/handle/ 10261/248177 with https://digital.csic.es/handle/10261/248177.

\section{Declaration}

Conflict of interest The authors declare no conflict or competing of interest.

Open Access This article is licensed under a Creative Commons Attribution 4.0 International License, which permits use, sharing, adaptation, distribution and reproduction in any medium or format, as long as you give appropriate credit to the original author(s) and the source, provide a link to the Creative Commons licence, and indicate if changes were made. The images or other third party material in this article are included in the article's Creative Commons licence, unless indicated otherwise in a credit line to the material. If material is not included in the article's Creative Commons licence and your intended use is not permitted by statutory regulation or exceeds the permitted use, you will need to obtain permission directly from the copyright holder. To view a copy of this licence, visit http://creativecommons.org/licenses/by/4.0/.

\section{References}

Ahmad-Ur-Rahman S, Naila A, Javed K et al (2016) Functional Response of Chrysoperla carnea Stephen (Neuroptera: Chrysopidae) fed on Cabbage aphid, Brevicoryne brassicae (Linnaeus) under laboratory conditions. Pak J Zool 48:165-169

Albrecht M, Kleijn D, Williams NM et al (2020) The effectiveness of flower strips and hedgerows on pest control, pollination services and crop yield: a quantitative synthesis. Ecol Lett 23:1488-1498. https://doi.org/10.1111/ele.13576

Alcalá Herrera R, Campos M, González-Salvadó M, Ruano F (2019a) Abundance and population decline factors of chrysopid juveniles in olive groves and adjacent trees. Insects 10(5):134. https://doi. org/10.3390/insects10050134

Alcalá Herrera R, Ruano F, Gálvez Ramírez C et al (2019b) Attraction of green lacewings (Neuroptera: Chrysopidae) to native plants used as ground cover in woody Mediterranean agroecosystems. Biol Control 139:104066. https://doi.org/10.1016/j.biocontrol. 2019.104066

Alcalá Herrera R, Fernández Sierra ML, Ruano F (2020) The suitability of native flowers as pollen sources for Chrysoperla lucasina 
(Neuroptera: Chrysopidae). PLoS One 15(10):e0239847. https:// doi.org/10.1371/journal.pone.0239847

Alford D V, Nilsson C, Ulber B (2003) Insect pests of oilseed rape crops. In: Alford DV (ed) Biocontrol of oilseed rape pests. Blackwell Publishing, Oxford

Andersson S, Marmolin C, Björkholm A-M (2013) Fjärilslarver i kålväxter Rapport från projektet "Integrerat växtskydd i grönsaker på friland", Hushållningssällskapet. Stort fokus på bekämpning av renkavle, Sweden

Andrade KA, Aguiar-Menezes EL, Goncalves-Esteves V et al (2017) Pollen Ingestion by Chrysoperla externa (Hagen) adults in a diversified organic agroecosystem. Neotrop Entomol 47(1):118-130. https://doi.org/10.1007/s13744-017-0537-8

Aparicio Y, Riudavets J, Gabarra R et al (2021) Can Insectary plants enhance the presence of natural enemies of the green peach aphid (Hemiptera: Aphididae) in mediterranean peach orchards? J Econ Entomol 114(2):784-793. https://doi.org/10.1093/jee/toaa298

Aspöck H, Aspöck U, Hölzel H (1980) Die Neuropteren Europas: eine zusammenfassende Darstellung der Systematik, Ökologie und Chorologie der Neuropteroidea (Megaloptera, Raphidioptera, Planipennia) Europas. Goecke \& Evers, Krefeld, Austria

Balmer O, Géneau CE, Belz E et al (2014) Wildflower companion plants increase pest parasitation and yield in cabbage fields: Experimental demonstration and call for caution. Biol Control 76:19-27. https://doi.org/10.1016/j.biocontrol.2014.04.008

Barrientos JA (2004) Curso práctico de entomología. Univ, Autònoma de Barcelona, Barcelona, Spain

Bates D, Maechler M (2019) Matrix: sparse and dense matrix classes and methods

Bates D, Mächler M, Bolker B, Walker S (2014) Fitting linear mixedeffects models using lme4. J Stat Softw 67:1-48

Bertolaccini I, Núñez-Pérez E, Tizado EJ (2011) Alternative plants hosts of legume aphids and predators in the province of León, Spain. Cienc e Investig Agrar 38:233-242

Bertrand C, Eckerter PW, Ammann L et al (2019) Seasonal shifts and complementary use of pollen sources by two bees, a lacewing and a ladybeetle species in European agricultural landscapes. J Appl Ecol 56:2431-2442. https://doi.org/10.1111/1365-2664.13483

Bianchi FJJA, Wackers FL (2008) Effects of flower attractiveness and nectar availability in field margins on biological control by parasitoids. Biol Control 46:400-408. https://doi.org/10.1016/j.bioco ntrol.2008.04.010

Bianchi FJJA, Schellhorn NA, Cunningham SA (2013) Habitat functionality for the ecosystem service of pest control: reproduction and feeding sites of pests and natural enemies. Agric For Entomol 15:12-23. https://doi.org/10.1111/j.1461-9563.2012.00586.x

Boller EF, Häni F, Poehling H-M (2004) Ecological infrastructures: ideabook on functional biodiversity at the farm level, IOBCwprs C. Landwirtschaftliche Beratungszentrale Lindau (LBL), Lindau

Bone NJ, Thomson LJ, Ridland PM et al (2009) Cover crops in Victorian apple orchards: effects on production, natural enemies and pests across a season. Crop Prot 28:675-683. https://doi.org/10. 1016/j.cropro.2009.03.021

Brooks ME, Kristensen K, van Benthem KJ et al (2017) glmmTMB balances speed and flexibility among packages for zero-inflated generalized linear mixed modeling. R J 9:378-400

Buchmann SL, O'Rourke MK (1991) Importance of pollen grain volumes for calculating bee diets. Grana 30:591-595. https://doi.org/ 10.1080/00173139109427817

Burleigh JG, Young JH, Morrison RD (1973) Strip-crossings effect on beneficial insects and spiders associated with cotton in Oklahoma. Environ Entomol 2:281-285

Cahenzli F, Sigsgaard L, Daniel C et al (2019) Perennial flower strips for pest control in organic apple orchards - A pan-European study. Agric Ecosyst Environ 278:43-53. https://doi.org/10.1016/j.agee. 2019.03.011
Canard M (2001) Natural food and feeding habits of lacewings. In: Whittington AE, McEwen PK, New TR (eds) Lacewings in the Crop Environment. Cambridge University Press, Cambridge, UK, pp 116-129

Chapman JW, Reynolds DR, Brooks SJ et al (2006) Seasonal variation in the migration strategies of the green lacewing Chrysoperla carnea species complex. Ecol Entomol 31:378-388. https://doi. org/10.1111/j.1365-2311.2006.00797.x

Colley M, Luna J (2000) Relative attractiveness of potential beneficial insectary plants to aphidophagous hoverflies (Diptera: Syrphidae). Environ Entomol 29:1054-1059

Conway G (2000) The doubly green revolution: Balancing food, proverty and environmental needs in the 21 st century. In: Lee DR, Barrett CB (eds) Tradeoffs or synergies? Agricultural intensification, economic development, and the environment. CABI, Cornell University Press, Ithaca, N.Y., p 538

Faegri K, Iversen J (1989) Textbook of pollen analysis, 4th edn. John Wiley and Sons, Chichester

Fahrig L, Baudry J, Brotons L et al (2011) Functional landscape heterogeneity and animal biodiversity in agricultural landscapes. Ecol Lett 14:101-112. https://doi.org/10.1111/j.1461-0248.2010. 01559.x

Fiedler AK, Landis DA, Wratten SD (2008) Maximizing ecosystem services from conservation biological control: The role of habitat management. Biol Control 45:254-271. https://doi.org/10.1016/j. biocontrol.2007.12.009

Fox J, Weisberg S (2019) An R Companion to Applied Regression, Third. Sage, Thousand Oaks, CA

Fye RE, Carranza RL (1972) Movement of insect predators from grain sorghum to cotton. Environ Entomol 1:790-791

Gonzalez D, Nave A, Gonçalves F et al (2016) Higher longevity and fecundity of Chrysoperla carnea, a predator of olive pests, on some native flowering Mediterranean plants. Agron Sustain Dev 36(30). https://doi.org/10.1007/s13593-016-0369-7

Goulet H, Huber JT, Canada A (1993) Hymenoptera of the world: an identification guide to families. Centre for Land and Biological Resources Research, Ottawa, Ontario, Canada

Gurr GM, Wratten SD, Landis DA, You M (2017) Habitat management to suppress pest populations: progress and prospects. Annu Rev Entomol 62:91-109. https://doi.org/10.1146/annur ev-ento-031616-035050

Haaland C, Gyllin M (2011) Sown wildflower strips-a strategy to enhance biodiversity and amenity in intensively used agricultural areas. In: Lopez Pujol J (ed) The Importance of Biological Interactions in the Study of Biodiversity. InTech, London

Hartig F (2018) DHARMa: Residual Diagnostics for Hierarchical (Multi-Level/Mixed) Regression Models. R package version 0.2.0

Hatt S, Uytenbroeck R, Lopes T et al (2019) Identification of flower functional traits affecting abundance of generalist predators in perennial multiple species wildflower strips. Arthropod Plant Interact 13:127-137. https://doi.org/10.1007/s11829-018-9652-7

Hatt S, Uyttenbroeck R, Lopes T, et al (2017) Do flower mixtures with high functional diversity enhance aphid predators in wildflower strips? Eur J Entomol 114:66-76. https://doi.org/10.14411/eje. 2017.010

Heimbach U, Müller A (2013) Incidence of pyrethroid-resistant oilseed rape pests in Germany. Pest Manag Sci 69:209-216. https://doi. org/10.1002/ps.3351

Henry CS, Brooks SJ, Duelli P, Johnson JB (2002) Discovering the true Chrysoperla carnea (Insecta: Neuroptera: Chrysopidae) using song analysis, morphology, and ecology. Ann Entomol Soc Am 95:172-191. https://doi.org/10.1603/0013-8746(2002)095[0172: dttcci]2.0.co;2

Henry CS, Brooks SJ, Duelli P et al (2013) Obligatory duetting behaviour in the Chrysoperla carnea-group of cryptic species 
(Neuroptera: Chrysopidae): its role in shaping evolutionary history. Biol Rev 88:787-808. https://doi.org/10.1111/brv.12027

Huang N, Enkegaard A (2010) Predation capacity and prey preference of Chrysoperla carnea on Pieris brassicae. BioControl 55:379385. https://doi.org/10.1007/s10526-009-9254-5

Irvin NA, Scarratt SL, Wratten SD et al (2006) The effects of floral understoreys on parasitism of leafrollers (Lepidoptera: Tortricidae) on apples in New Zealand. Agric For Entomol 8:25-34. https://doi.org/10.1111/j.1461-9555.2006.00285.x

Jones GD (2014) Pollen analyses for pollination research, acetolysis. J Poll Ecol 13:203-217

Klingen I, Johansen NS, Hofsvang T (1996) The predation of Chrysoperla carnea (Neurop., Chrysopidae) on eggs and larvae of Mamestra brassicae (Lep., Noctuidae). J Appl Entomol 120:363367. https://doi.org/10.1111/j.1439-0418.1996.tb01620.x

Landis DA, Wratten SD, Gurr GM (2000) Habitat management to conserve natural enemies of arthropod pests in agriculture. Annu Rev Entomol 45:175-201. https://doi.org/10.1146/annurev.ento. 45.1.175

Lee JC, Heimpel GE (2005) Impact of flowering buckwheat on Lepidopteran cabbage pests and their parasitoids at two spatial scales. Biol Control 34:290-301. https://doi.org/10.1016/j.biocontrol. 2005.06.002

Lenth RV (2016) Least-squares means: The R package lsmeans. J Stat Softw 69:. https://doi.org/10.18637/jss.v069.i01

Lenth R (2020) emmeans: Estimated Marginal Means, aka LeastSquares Means

Martin EA, Dainese M, Clough Y et al (2019) The interplay of landscape composition and configuration: new pathways to manage functional biodiversity and agroecosystem services across Europe. Ecol Lett 22:1083-1094. https://doi.org/10.1111/ele.13265

McEwen PK, Ruiz J (1994) Relationship between non-olive vegetation and green lacewing eggs in a Spanish olive orchard. Antenna 18:148-150

Medeiros MA, Ribeiro PA, Morais HC et al (2010) Identification of plant families associated with the predators Chrysoperla externa (Hagen) (Neuroptera: Chrysopidae) and Hippodamia convergens Guerin-Meneville (Coleoptera: Coccinelidae) using pollen grain as a natural marker. Brazilian J Biol 70:293-300. https://doi.org/ 10.1590/s1519-69842010005000011

Monserrat VJ (2016) Los crisópidos de la Península Ibérica y Baleares (Insecta, Neuropterida, Neuroptera: Chrysopidae). Graellsia 72:1123 (In Spanish). https://doi.org/10.3989/graellsia.2016.v72.143

Morris MC, Li FY (2000) Coriander (Coriandrum sativum) "companion plants" can attract hoverflies, and may reduce pest infestation in cabbages. New Zeal J Crop Hortic Sci 28:213-217. https://doi. org/10.1080/01140671.2000.9514141

Nave A (2016) Enhancing biological control of the olive moth, Prays oleae (Bernard) (Lepidoptera: Praydidae) in organic olive groves by increasing fuctional biodiversity. Universidade de Trás-osMontes e Alto Douro

Nicholls CI, Parrella M, Altieri MA (2001) The effects of a vegetational corridor on the abundance and dispersal of insect biodiversity within a northern California organic vineyard. Landsc Ecol 16:133-146. https://doi.org/10.1023/A:1011128222867

Nilsson U, Porcel M, Świergiel W, Wivstad M (2016) Habitat manipulation - as a pest management tool in vegetable and fruit cropping systems, with the focus on insects and mites. SLU, EPOK - Centre for Organic Food \& Farming, Uppsala

Oksanen J, Guillaume Blanchet F, Friendly M, et al (2018) vegan: Community Ecology Package

Pappas ML, Broufas GD, Koveos DS (2011) Chrysopid predators and their role in biological control. J Entomol 8:301-326

Penvern S, Fernique S, Cardona A et al (2019) Farmers' management of functional biodiversity goes beyond pest management in organic European apple orchards. Agric Ecosyst Environ 284:106555. https://doi.org/10.1016/j.agee.2019.05.014

Pfiffner L, Luka H, Schlatter C et al (2009) Impact of wildflower strips on biological control of cabbage lepidopterans. Agric Ecosyst Environ 129:310-314. https://doi.org/10.1016/j.agee.2008.10.003

Plant CW (2013) A key to the adults of British lacewings and their allies (Neuroptera, Megaloptera, Raphidioptera and Mecoptera). Field Studies Council, Shrewsbury

Porcel M, Cotes B, Castro J, Campos M (2017) The effect of resident vegetation cover on abundance and diversity of green lacewings (Neuroptera: Chrysopidae) on olive trees. J Pest Sci 90:195-196. https://doi.org/10.1007/s10340-016-0748-5

Price BW, Henry CS, Hall AC et al (2015) Singing from the grave: DNA from a 180 year old type specimen confirms the identity of Chrysoperla carnea (Stephens). PLoS One 10:11. https://doi.org/ 10.1371/journal.pone.0121127

Principi MM, Canard M (1984) Feeding habits. In: Canard M, Séméria Y, New TR (eds) Biology of Chrysopidae. Junk Publishers, The Hague, NL, Dr. W, pp 76-92

Punt W, Clarke GCS (1980) The Northwest European pollen flora. Elsevier, Amsterdam

R Development Core Team (2017) R: A Language and Environment for Statistical Computing

Reddy GVP, Tabone E, Smith MT (2004) Mediation of host selection and oviposition behavior in the diamondback moth Plutella xylostella and its predator Chrysoperla carnea by chemical cues from cole crops. Biol Control 29:270-277. https://doi.org/10.1016/ S1049-9644(03)00162-2

Resende ALS, Souza B, Ferreira RB, Aguiar-Menezes EL (2017) Flowers of Apiaceous species as sources of pollen for adults of Chrysoperla externa (Hagen) (Neuroptera). Biol Control 106:40-44. https://doi.org/10.1016/j.biocontrol.2016.12.007

Ridgway RL, Murphy WL (1984) Biological control in the field. In: Canard M, Séméria Y, New TR (eds) Biology of Chrysopidae. Junk Publishers, The Hague, Dr. W, pp 220-227

Robinson KA, Jonsson M, Wratten SD et al (2008) Implications of floral resources for predation by an omnivorous lacewing. Basic Appl Ecol 9:172-181

RStudio Team (2016) RStudio: Integrated Development Environment for $\mathrm{R}$

SCB (2018) Skörd av trädgårdsväxter 2017. Statistiska meddelande 2018. Frösön, Sweden

Serée L, Rouzes R, Thiéry D, Rusch A (2020) Temporal variation of the effects of landscape composition on lacewings (Chrysopidae: Neuroptera) in vineyards. Agric For Entomol 22(3):274-283 https://doi.org/10.1111/afe.12380

Sievwright HC, Sutton GL, Rosenfeld A (2006) Plants for predatorsa participatory experiment. In: Aspects of Applied Biology 78, What will organic farming deliver? Association of Applied Biologists, Warwick, pp 121-124

Silva EB, Franco JC, Vasconcelos T, Branco M (2010) Effect of ground cover vegetation on the abundance and diversity of beneficial arthropods in citrus orchards. Bull Entomol Res 100:489-499. https://doi.org/10.1017/s0007485309990526

Smith MW, Arnold DC, Eikenbary RD et al (1996) Influence of ground cover on beneficial arthropods in pecan. Biol Control 6:164-176. https://doi.org/10.1006/bcon.1996.0021

Steffen W, Richardson K, Rockström J et al (2015) Planetary boundaries: Guiding human development on a changing planet. Science 347:6223. https://doi.org/10.1126/science.1259855

Stelzl M (1991) Untersuchungen zu Nahrungsspektren mitteleuropäischer Neuropteren-Imagines (Neuropteroidea, Insecta) mit einer Diskussion über deren Nützlichkeit als Opponenten von Pflanzenschädlingen. J Appl Entomol 111:469-477

Stelzl M (1992) Comparative studies on mouthparts and feeding habits of adult Raphidioptera and Neuroptera (Insecta: Neuropteroidea). 
In: Current research in neuropterology: Proceedings of the Fourth International Symposium on Neuropterology, Bagneres-deLuchon, Haute-Garonne, France, 24-27 June 1991. Universite Paul-Sabatier

Tilman D, Cassman KG, Matson PA et al (2002) Agricultural sustainability and intensive production practices. Nature 418:671-677. https://doi.org/10.1038/nature01014

Tittonell P (2014) Ecological intensification of agriculture-sustainable by nature. Curr Opin Environ Sustain 8:53-61. https://doi.org/10. 1016/j.cosust.2014.08.006

Tscharntke T, Karp DS, Chaplin-Kramer R, et al (2016) When natural habitat fails to enhance biological pest control - Five hypotheses. Biol Conserv 204:449-458. https://doi.org/10.1016/j.biocon.2016. 10.001

Tschumi M, Albrecht M, Collatz J et al (2016) Tailored flower strips promote natural enemy biodiversity and pest control in potato crops. J Appl Ecol 53:1169-1176. https://doi.org/10.1111/13652664.12653

Valdés B, Díez MJ, Fernández I (1987) Atlas polínico de Andalucía occidental, $1^{\text {a }}$. Instituto de Desarrollo Regional, Universidad de Sevilla, Excma, Diputacion de Cádiz, Utrera, Sevilla, Spain

Van Rijn PCJ (2012) The suitability of field margin flowers as food source for Chrysoperla lacewings. IOBC/WPRS Bull 75:213-216

Van Rijn PCJ, Wackers FL (2016) Nectar accessibility determines fitness, flower choice and abundance of hoverflies that provide natural pest control. J Appl Ecol 53:925-933. https://doi.org/10. 1111/1365-2664.12605

Verkerk R (2001) Farmers' friends-recognition and conservation of natural enemies of vegetable pests. Department of Biology, Imperial Colloge of Science, Technology \& Medicine, University of London, London

Villa M, Marrao R, Mexia A et al (2017) Are wild flowers and insect honeydews potential food resources for adults of the olive moth, Prays oleae? J Pest Sci 90:185-194. https://doi.org/10.1007/ s10340-016-0745-8
Villa M, Santos SAP, Benhadi-Marín J et al (2016) Life-history parameters of Chrysoperla carnea s.l. fed on spontaneous plant species and insect honeydews: importance for conservation biological control. BioControl 61:533-543. https://doi.org/10.1007/ s10526-016-9735-2

Villa M, Somavilla I, Santos SAP, et al (2019) Pollen feeding habits of Chrysoperla carnea s.l. adults in the olive grove agroecosystem. Agric Ecosyst Environ 283:106573. https://doi.org/10.1016/j. agee.2019.106573

Villenave J, Thierry D, Al Mamun A et al (2005) The pollens consumed by common green lacewings Chrysoperla spp. (Neuroptera: Chrysopidae) in cabbage crop environment in western France. Eur J Entomol 102:547-552

Villenave J, Deutsch B, Lode T, Rat-Morris E (2006) Pollen preference of the Chrysoperla species (Neuroptera: Chrysopidae) occurring in the crop environment in western France. Eur J Entomol 103:771-777

Wilkinson TK, Landis DA (2005) Habitat diversification in biological control: the role of plant resources. In: Wäckers FL, Bruin J, van Rijn PCJ (eds) Plant-provided food for carnivorous insects: a protective mutualism and its applications. Cambridge University Press, Cambridge, pp 305-325

Winkler K, Wäckers F, Pinto DM (2009) Nectar-providing plants enhance the energetic state of herbivores as well as their parasitoids under field conditions. Ecol Entomol 34:221-227. https:// doi.org/10.1111/j.1365-2311.2008.01059.x

Wyss E (1995) The effects of weed strips on aphids and aphidophagous predators in an apple orchard. Entomol Exp Appl 75:43-49

Zhao JZ, Ayers GS, Grafius EJ, Stehr FW (1992) Effects of neighboring nectar-producing plants on population pest Lepidoptera and their parasitoids in broccoli plantings. Gt Lakes Entomol 25:253-258

Publisher's Note Springer Nature remains neutral with regard to jurisdictional claims in published maps and institutional affiliations. 